\title{
Genetic divergence and phosphorus use efficiency in the soybean with a view to biodiesel production ${ }^{1}$
}

\author{
Divergência genética e eficiência do uso do fósforo na soja visando à produção de \\ biodiesel
}

\author{
Evandro Reina ${ }^{2}$, Joênes Mucci Peluzio ${ }^{3 *}$, Flavio Sergio Afferri ${ }^{4}$, Waldesse Piragé Oliveira Junior ${ }^{3}$ Susana \\ Cristine Siebeneichler ${ }^{4}$
}

\begin{abstract}
The soybean has an important role in the area of biodiesel, due to having a productive potential and technical feasibility able to meet the growing demand for renewable fuels. In the agricultural year of 2009/10, four competitive trials of soybean cultivars were carried out, two on the Campus of Palmas University and the other two on the University Campus at Gurupi, with a study of genetic divergence being undertaken. At each location, the cultivars were trained under conditions of both high and low phosphorus ( $150 \mathrm{~kg} \mathrm{ha}^{-1} \mathrm{P}_{2} \mathrm{O}_{5}$ and $30 \mathrm{~kg} \mathrm{ha}^{-1} \mathrm{P}_{2} \mathrm{O}_{5}$ respectively). The experimental design employed for each trial was of randomised blocks with three replications and 11 treatments. The percentage of oil as a characteristic was studied, and the efficiency of phosphorus usage by the cultivars determined employing the methodology adapted from Fischer (1983). Genetic divergence was evaluated using multivariate procedures: the generalised Mahalanobis distance and Tocher's optimisation method for clustering. In the study of genetic divergence, each test represented a distinct variable in the multivariate model. The cultivars M-SOY 9350, M 8766RR and BR/EMGOPA 314 are the most suitable for the production of biodiesel. The hybrids M 8766RR x M 9056RR, BR/EMGOPA 314 x M 9056RR, P98R91 x M 9056RR are promising for obtaining segregating populations to be used for their oil content.
\end{abstract}

Key words: Glycine max. Oil content. Biofuel.

RESUMO - A cultura da soja tem papel importante na questão do biodiesel, por apresentar potencial produtivo e viabilidade técnica capaz de atender parte da crescente demanda por combustíveis renováveis. No ano agrícola 2009/10, foram realizados quatro ensaios de competição de cultivares de soja, sendo dois no Campus Universitário de Palmas e outros dois no Campus Universitário de Gurupi e realizado um estudo de divergência genética. Em cada local, as cultivares foram conduzidas sob alto e baixo fósforo (150 kg ha-1 de $\mathrm{P}_{2} \mathrm{O}_{5}$ e $30 \mathrm{~kg} \mathrm{ha}^{-1}$ de $\mathrm{P}_{2} \mathrm{O}_{5}$ respectivamente). $\mathrm{O}$ delineamento experimental utilizado, em cada ensaio, foi de blocos casualisados com três repetições e 11 tratamentos. Foi estudada a característica percentagem de óleo e determinada a eficiência do uso de fósforo pelas cultivares, através da metodologia adaptada de Fischer (1983). A divergência genética foi avaliada por meio de procedimentos multivariados: distância generalizada de Mahalanobis e método de agrupamento de otimização de Tocher. No estudo da divergência genética, cada ensaio representou uma variável distinta no modelo multivariado. As cultivares M-SOY 9350, M 8766RR e BR/EMGOPA 314 são as mais indicadas para a produção de biodiesel. As hibridações M 8766RR x M 9056RR, BR/ EMGOPA 314 x M 9056RR, P98R91 x M 9056RR são promissoras para obtenção de populações segregantes para teor de óleo.

Palavras-chave: Glycine max. Teor de óleo. Bicombustível.

\footnotetext{
* Autor para correspondência

${ }^{1}$ Recebido para publicação em 05/09/2011; aprovado em 22/12/2013

Parte da Dissertação de Mestrado do primeiro autor apresentada na Fundação Universidade Federal do Tocantins-UFT, Mestrado em Agroenergia

${ }^{2}$ Campus Universitário de Palmas, Universidade Federal do Tocantins, Palmas-TO, Brasil, evandro_reina@yahoo.com.br

${ }^{3}$ Campus Universitário de Palmas no Curso de Mestrado em Agroenergia, Universidade Federal do Tocantins, Palmas-TO, Brasil, joenesp@ uft.edu.br, waldessejunior@uft.edu.br

${ }^{4}$ Campus Universitário de Gurupi, Universidade Federal do Tocantins, Gurupi-TO, Brasil, flavio@uft.edu.br, suzanacristines@uft.edu.br
} 


\section{INTRODUCTION}

In the State of Tocantins in Brazil, the cultivation of oilseed plants has increased in recent years due to the abundance of water resources, the favourable edaphoclimatic conditions, the strategic location of the BR 153 highway, implementation of the North-South railway and of the Tocantins-Araguaia Waterway (PELUZIO et al., 2006).

In government plans for expanding the production of biodiesel, the soybean represents the main source of raw materials, since there is a structured production chain and the mastering of technology able to meet part of the growing demand for renewable fuels (GOLDEMBERG et al., 2008).

As part of its composition the soybean has $20 \%$ oil, $38 \%$ protein and $34 \%$ carbohydrates, as well as fibre and inorganic constituents (EMPRESA BRASILEIRA DE PESQUISA AGROPECUÁRIA, 2010). This composition varies according to genetics and the environmental conditions, causing variations in industrial productivity (SBARDELOTTO; LEANDRO, 2008).

In the Brazilian savanna, or cerrado, the soils predominantly show a high degree of weathering, with marked features such as acidity, a high degree of leaching and low fertility, especially in the phosphorus (P) available to plants (PIAIA et al., 2002). Determining the dosage of phosphorus to be applied to a crop directly affects productivity, since under low levels of phosphorus there is a sharp fall in productivity, due to a reduction in the size of the plant, the height of insertion of the first pods, and the number of flowers and pods (VALADÃO JÚNIOR et al., 2008).

The study of soybean genotypes which have adapted to low phosphorous fertility $(\mathrm{P})$ is of economic and environmental importance. Under conditions of low phosphorous availability in the soil, strains and soybean cultivars which are suitable for and efficient in the use of this nutrient, show better productive performance. Obtaining these efficient genotypes will be possible with a better understanding of the physiological and genetic bases for phosphorus use efficiency (PUE) (LIAO et al., 2006).

In breeding programs, it is necessary to have knowledge of how developed characteristics are inherited and of the genetic background of the parent plants; this information being obtained through the study of genetic divergence (CEOLIN et al., 2007; MACHADO et al., 2002; RODRIGUES et al., 2002).

In this respect, it is through the study of genetic diversity among individuals or populations, using agronomic, morphological and molecular characteristics to which, in turn are applied multivariate biometric techniques, unifying different information from a set of characteristics and providing guidelines for crossings which result in hybrid combinations of higher heterozygosity, that there is a greater possibility of obtaining superior genotypes in segregating generations (CLEMENTE, CAHOON, 2009; FERRÃO et al., 2002). Among the multivariate statistical techniques are the Tocher method for clustering and the nearest-neighbour optimisation (CRUZ; REGAZZI, 2004).

Thus, due to the soybean having the potential for use as a source of biofuel, coupled with the low natural fertility of soils in the cerrado, studies should be carried out into phosphorus use efficiency for the characteristic of the grain oil content, as well as a study into genetic divergence, both of which this paper proposes to do.

\section{MATERIALS AND METHODS}

In the crop year of $2009 / 10$, four competition trials of soybean cultivars were held, two in the Centre for Agrotechnology of the Federal University of Tocantins, at Palmas Campus (altitude $220 \mathrm{~m}, 10^{\circ} 45^{\prime} \mathrm{S}$ and $47^{\circ} 14^{\prime} \mathrm{W}$ ) and two at the Experimental Station of the Tocantins Federal University, at Gurupi Campus (altitude $280 \mathrm{~m}$, $11^{\circ} 43^{\prime} \mathrm{S}$ and $49^{\circ} 04^{\prime} \mathrm{W}$ ). At each site the cultivars were sown under conditions of both high and low phosphorous (150 kg $\mathrm{P}_{2} \mathrm{O}_{5} \mathrm{ha}^{-1}$ and $30 \mathrm{~kg} \mathrm{P}_{2} \mathrm{O}_{5} \mathrm{~h}^{-1}$ respectively), with planting being carried out on 17 December 2009 in Palmas, and on 29 November 2009 in Gurupi, in a dystrophic redyellow Latosol.

To define usage of the high and low dosages of phosphorus, an analysis of the soil from each site was initially carried out, giving the following results: Palmas: pH 4.9, K $35.2 \mathrm{mg} \mathrm{dm}{ }^{-3}$, P $6.0 \mathrm{mg} \mathrm{dm}^{-3}$, OM 0.6\%; CEC 4.7 e SB 33,3\%; Gurupi: pH 5.1, K $93 \mathrm{mg}$ $\mathrm{dm}^{-3}, \mathrm{P} 5.3 \mathrm{mg} \mathrm{dm}^{-3}$, OM 0.6\%, CEC 5.44 e SB $59.56 \%$. Then an indication of fertilisation was found, which resulted in a dosage of $60 \mathrm{~kg} \mathrm{P}_{2} \mathrm{O}_{5} \mathrm{ha}^{-1}$. Based on this, dosages below and above that recommended were used, i.e. $30 \mathrm{~kg} \mathrm{P}_{2} \mathrm{O}_{5} \mathrm{ha}^{-1}$ and $150 \mathrm{~kg} \mathrm{P}_{2} \mathrm{O}_{5} \mathrm{ha}^{-1}$.

The experimental design used in each trial was of randomised blocks, with 11 treatments and three replications. The treatments consisted of the cultivars P98Y51, P98Y70, P99R01, P98R91, M 9056RR, M 9144RR, M 8766RR, M 8867RR, M 8527RR, M-SOY 9350 and BR/EMGOPA 314.

The experimental plots were made up of four rows, each $5 \mathrm{~m}$ in length, with spacing between rows of $0.45 \mathrm{~cm}$. When harvesting, the two central rows 
were used, excluding $0.50 \mathrm{~m}$ from the end of each row, resulting in a usable area of $3.6 \mathrm{~m}^{2}$.

Ploughing, harrowing and furrowing were carried out. Planting the seeds and fertilisation in the furrows were performed manually. Fertilisation was done at sowing, using 166 and $833 \mathrm{~kg} \mathrm{ha}^{-1}$ of single superphosphate which correspond respectively to dosages of $30 \mathrm{~kg}$ (low) and 150 (high) $\mathrm{kg}$ of $\mathrm{P}_{2} \mathrm{O}_{5}$ per hectare.

Two cover fertilisations of potassium chloride were carried out at a dosage of $55 \mathrm{~kg} \mathrm{ha}^{-1}$ of $\mathrm{K}_{2} \mathrm{O}(92 \mathrm{~kg}$ of potassium chloride per hectare) in Palmas, and two cover fertilisations at a dosage of $30 \mathrm{~kg} \mathrm{ha}^{-1}$ of $\mathrm{K}_{2} \mathrm{O}(50 \mathrm{~kg}$ of potassium chloride per hectare) in Gurupi, as per the soil analysis and the indication of corrective fertilisation. Cover fertilisation took place at 15 and 35 days after plant emergence respectively.

When planted, the seeds were treated with fungicides followed by inoculation with strains of Bradyrhizobium japonicum. Seeding density was chosen in order to get 14 plants per linear metre. Pest, disease and weed control were carried out as needed.

The plants in each experimental plot were harvested one week after having presented $95 \%$ ripe pods, i.e. at the $\mathrm{R}_{8}$ stage on the scale by Fehr et al. (1971).

Based on the usable area of the plot, moisture correction to $12 \%$ was carried out. Three samples containing 100 grams of grain were then taken from each plot. The oil content of the grains (\%) was subsequently determined in the laboratory of the College for Food Engineering at the Federal University of Tocantins in Palmas, using the Soxhlet method following recommendations of the Adolfo Lutz Institute (2005).

Using values from data obtained under low and high phosphorus, the phosphorus use efficiency was evaluated for each cultivar, as per a method adapted from Fischer et al. (1983), from the PUE index obtained with equation 1 :

$$
P U E=Y a(-P) / Y a(+P) x Y x(-P) / Y x(+P)
$$

where $Y a(-P)$ is the yield for genotype "a" under low $\mathrm{P} ; \mathrm{Ya}(+P)$ is the yield for genotype "a" under high $\mathrm{P}$; $Y x(-P)$ is the average yield for all genotypes under low $\mathrm{P} ; Y x(+P)$ is the average yield for all genotypes under high $\mathrm{P}$.

A PUE index is used to classify a cultivar as efficient (index above the average under high and low phosphorous) and not efficient (index below the average under high and low phosphorous), as the averages for the cultivars under high and low phosphorus are used.
Variance analysis was carried out for each test, followed by a combined analysis for all those tests where the lowest residual mean square did not differ from the highest by more than seven times (CRUZ; REGAZZI, 2004).

For the efficiency index, variance analysis was carried out for the variable, oil content (\%). Means were compared by Scott-Knott test at a 5\% level of significance. The Student t-test, at a level of significance of $5 \%$, was also used to compare the efficiency indices of the cultivars to the general efficiency index after having tested the normality of the data using the Kolmogorov-Smirnov test.

Using the four trials as variables in the multivariate model, a study of genetic diversity among cultivars was conducted, where each test represented a distinct variable in the model. Measures of dissimilarity were determined using multivariate analysis, which allowed the dissimilarity matrix, the residual covariance matrix and the averages for the cultivars to be obtained.

The Tocher method of clustering proposed by RAO (1952) was applied using the generalised Mahalanobis distance $\left(\mathrm{D}^{2}\right)$ as a measure of dissimilarity. Analyses were performed using the Computational Genes software, version 2007 (CRUZ, 2007).

\section{RESULTS AND DISCUSSION}

The combined variance analysis (Table 1) showed significant effects from the cultivar, environment and interaction of cultivar and environment, the latter indicating that the isolated effects of the factors of cultivar and environment do not explain all the variation found, and because of this the data were split.

Table 1 - Summary of the variance analysis for oil content (\%) of 11 soybean cultivars from the 2009/10 crop

\begin{tabular}{lccc}
\hline \multicolumn{1}{c}{ Source of Variance } & GL & QM & F \\
\hline Block/env. & 8 & 0.14 & $0.2153^{\text {ns }}$ \\
Cultivar & 10 & 12.01 & $17.6617^{*}$ \\
Environment & 3 & 3.54 & $5.2058^{*}$ \\
Cult.x env. & 30 & 2.2 & $3.2352^{*}$ \\
Error & 80 & 0.68 \\
Mean & \multicolumn{3}{c}{3.26} \\
\hline CV \% & 3.89 \\
ns: not significant; * significant at 5\% by F-test
\end{tabular}

The significance for the cultivars indicates the existence of genetic variability and the possibility of 
obtaining genetic gains. The coefficients of variation were low, indicating good accuracy in the experiments (SCAPIM; CARVALHO; CRUZ, 1995).

In the environments under high phosphorus at Palmas and Gurupi, similarity was seen in the number of clusters formed and in the composition of these clusters (Table 2). The highest percentages for oil were obtained in: M 8766RR; BR/EMGOPA 314; P98R91; M-SOY 9350; P98Y51; M 9144RR and M 9056RR. In the group having lower averages, are found the cultivars: P99R01; M 8527RR; P98Y70 and M 8867RR.

For Palmas and Gurupi under low phosphorus, three clusters of averages were formed, but there was no similarity in the composition of the clusters (Table $2)$. In both locations the cultivars with the highest percentages of oil were M 8766RR, M 9144 RR and $\mathrm{BR} / \mathrm{EMGOPA}$ 314. These also stood out in the same locations under high phosphorus. On the other hand, in Palmas the lowest value for oil content was obtained from the cultivar P98Y70 and in Gurupi by the cultivars M 8867RR, M 8527RR and M 9056RR.

For each cultivar, study of the location independently of the dosages of phosphorus showed a trend for higher oil content in Palmas. This probably happened due to the occurrence of higher average temperatures and lower rainfall in Palmas in relation to Gurupi, at 20-40 days before grain maturation (grain fill) (Figures 1 and 2).
These results are in agreement with those obtained by Albrecht et al. (2008), Barbosa et al. (2011), Minuzzi et al. (2009) who also observed the effects of high temperatures and reductions in water on the increase in oil content in soybeans, which resulted in biochemical disturbances in oil biosynthesis. However, Maehler et al. (2003), when working with two soybean cultivars under two water regimes (irrigated and nonirrigated), found that the oil content of the grains was not changed.

Figure 1 - Average precipitation from December 2009 to April 2010 in Palmas and Gurupi, Tocantins

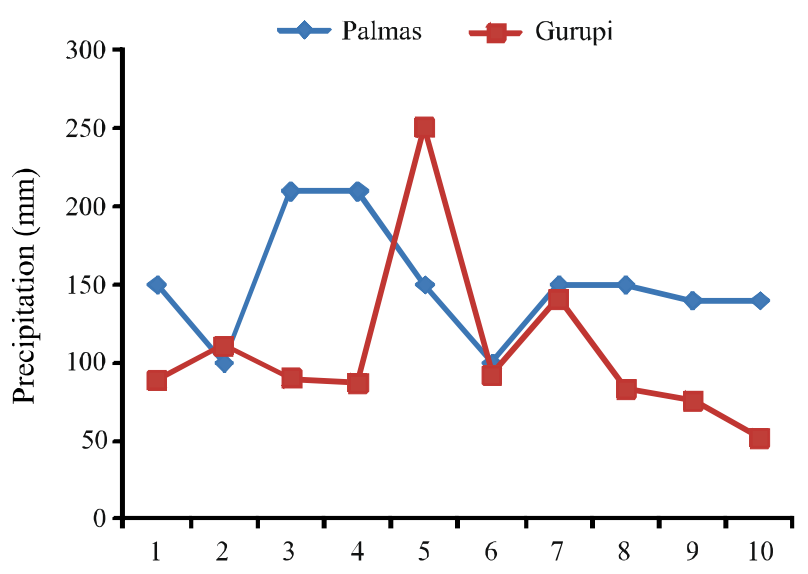

Table 2 - Means for oil content (\%) and Phosphorus Use Efficiency (PUE), using a methodology adapted from Fischer et al. (1983), of 11 soybean cultivars under high and low phosphorus, in Palmas and Gurupi, from the 2009/10 crop

\begin{tabular}{|c|c|c|c|c|c|c|}
\hline \multirow{2}{*}{$\% \mathrm{OIL}$} & \multicolumn{2}{|c|}{ PALMAS } & \multicolumn{2}{|c|}{ GURUPI } & \multirow{2}{*}{ MEAN } & \multirow{2}{*}{$\begin{array}{l}\text { EUP Oi } \\
\text { Content }\end{array}$} \\
\hline & LOW & HIGH & LOW & HIGH & & \\
\hline P98Y51 & $21.5 \mathrm{aB}$ & $22.3 \mathrm{aA}$ & $22.6 \mathrm{aA}$ & $21.2 \mathrm{aA}$ & $21.9 \mathrm{~A}$ & $1.00 \mathrm{a}$ \\
\hline P98Y70 & $18.6 \mathrm{bC}$ & $21.3 \mathrm{aB}$ & $20.4 \mathrm{aB}$ & $19.9 \mathrm{bB}$ & $20.0 \mathrm{~B}$ & $0.97 \mathrm{a}$ \\
\hline P99R01 & $20.7 \mathrm{aB}$ & $21.3 \mathrm{aB}$ & $20.2 \mathrm{aB}$ & $19.2 \mathrm{bB}$ & $20.4 \mathrm{~B}$ & $1.00 \mathrm{a}$ \\
\hline P98R91 & $21.1 \mathrm{aB}$ & $22.6 \mathrm{aA}$ & $22.6 \mathrm{aA}$ & $22.1 \mathrm{aA}$ & $22.1 \mathrm{~A}$ & $0.98 \mathrm{a}$ \\
\hline M 9056RR & $21.5 \mathrm{aB}$ & $22.9 \mathrm{aA}$ & $19.4 \mathrm{bC}$ & $21.8 \mathrm{aA}$ & $21.4 \mathrm{~A}$ & $0.95 \mathrm{a}$ \\
\hline M 9144RR & $22.5 \mathrm{aA}$ & $21.9 \mathrm{aA}$ & $21.2 \mathrm{aA}$ & $21.5 \mathrm{aA}$ & $21.8 \mathrm{~A}$ & $0.99 \mathrm{a}$ \\
\hline M 8766RR & $22.6 \mathrm{aA}$ & $22.5 \mathrm{aA}$ & $22.0 \mathrm{aA}$ & $22.1 \mathrm{aA}$ & $22.3 \mathrm{~A}$ & $1.00 \mathrm{a}$ \\
\hline M 8867RR & $20.5 \mathrm{aB}$ & $19.9 \mathrm{aB}$ & $19.0 \mathrm{aC}$ & $19.3 \mathrm{aB}$ & $19.7 \mathrm{~B}$ & $1.00 \mathrm{a}$ \\
\hline M 8527RR & $21.7 \mathrm{aB}$ & $20.1 \mathrm{aB}$ & $19.0 \mathrm{bC}$ & $19.6 \mathrm{bB}$ & $20.1 \mathrm{~B}$ & $1.01 \mathrm{a}$ \\
\hline M-SOY 9350 & $20.8 \mathrm{aB}$ & $22.2 \mathrm{aA}$ & $23.0 \mathrm{aA}$ & $22.1 \mathrm{aA}$ & $22.0 \mathrm{~A}$ & $0.99 \mathrm{a}$ \\
\hline $\begin{array}{l}\text { BR/EMGOPA } \\
314\end{array}$ & $22.7 \mathrm{aA}$ & $21.8 \mathrm{aA}$ & $22.9 \mathrm{aA}$ & $21.4 \mathrm{aA}$ & $22.2 \mathrm{~A}$ & $1.02 * \mathrm{a}$ \\
\hline MEAN & $21.3 \mathrm{~B}$ & $21.7 \mathrm{~A}$ & $21.1 \mathrm{~B}$ & $20.9 \mathrm{~B}$ & 21.3 & 0.99 \\
\hline
\end{tabular}

Means followed by the same lowercase letter on a line, and uppercase letter in a column do not differ from each other at $5 \%$ by Scott-Knott test; *Averages statistically different from the general mean, by t-test at $5 \%$ 
Figura 2 - Average temperatures from December 2009 to April 2010 in Palmas and Gurupi, Tocatins

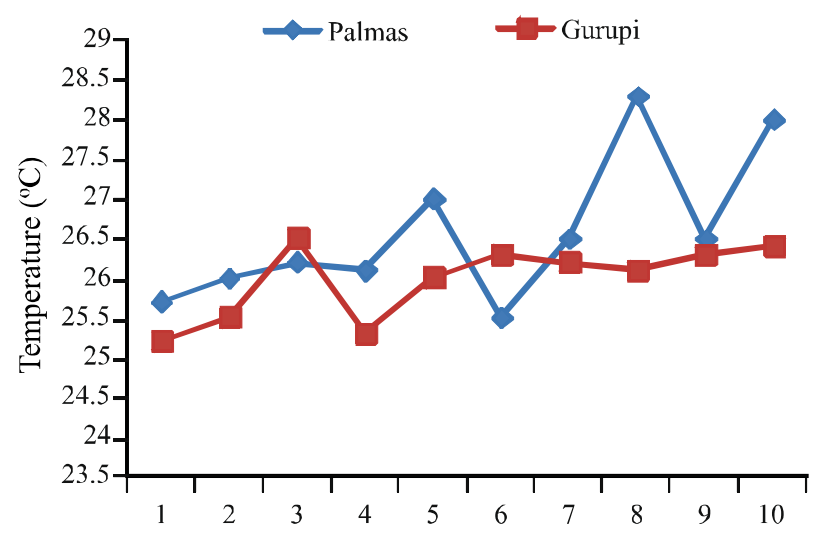

The summary of the variance analysis for phosphorus use efficiency in the crop for the characteristic of oil content, can be seen in Table 3. The coefficient of variation indicates good precision in conducting the experiments (SCAPIM; CARVALHO; CRUZ, 1995).

Table 3 - Summary of variance analysis for phosphorus use efficiency, using a methodology adapted from Fischer et al. (1983), for oil content (\%) in 11 soybean cultivars from the 2009/10 crop

\begin{tabular}{lrcl}
\hline Source of Variance & GL & QM $^{1 /}$ & F \\
\hline Blocks & 5 & 0.002 & 2.0 \\
Cultivar & 10 & 0.002 & $2.0^{\mathrm{ns}}$ \\
Error & 50 & 0.001 & \\
Mean & & 0.99 & \\
\hline CV \% & 3.25 & \\
${ }^{1 /}$ Data transformed to square root of X; ns: not significant; * significant \\
at 5\% by Scott-Knott test
\end{tabular}

No significant differences were detected among cultivars as regards phosphorus use efficiency (Table 2). This was probably due to the similarity in behaviour of the cultivars under high and low phosphorus at the studied locations (Table 2).

The indices of phosphorus use efficiency showed a normal distribution $(\mathrm{p}>0.05)$ according to Kolmogorov-Smirnov, and the t-test may be used. For this variable all cultivars showed phosphorus use efficiency indices above the average index (0.99), except for P98Y70 (0.97), P98R91 (0.91) and M 9056RR (0.95) (Table 2). Among the most efficient cultivars, BR/EMGOPA 314 was statistically superior (1.02) to the average efficiency index, and along with M 8766RR and M-SOY 9350, showed better performance for all the environments under study (Table 2).

The measurements of genetic dissimilarity, estimated from the Mahalanobis distance (Table 4) for the characteristic of oil content, showed a high magnitude (0.59 to 50.74), indicating the presence of ample genetic variability among the cultivars.

The combination between M-SOY 9350 and M 8867RR was the most divergent $\left(\mathrm{D}^{2}=50.74\right)$, followed by the combinations M 8527RR and M-SOY $9350\left(\mathrm{D}^{2}\right.$ $=49.33)$ and the pairs P98R91 and M 8867RR $\left(\mathrm{D}^{2}=\right.$ 49.30). The shortest distance was obtained between the cultivars M-SOY 9350 and P98R91 ( $\left.{ }^{2}=0.59\right)$, followed by the pairs M 8867RR and M 8527RR (D ${ }^{2}$ $=1.88), \mathrm{M}$ 8766RR and M 9144RR $\left(\mathrm{D}^{2}=2.1\right)$. Among the greatest distances found, the cultivar M 8867RR was present in over $63 \%$ of the combinations.

Cluster analysis by the Tocher method separated the 11 cultivars into four genetically distinct clusters for the characteristic of oil content (Table 5). Group I comprised $55 \%$ of the total cultivars, being those which presented the highest oil content. For groups II (M 8867RR, M 8527RR and P99R01) and III (P98Y70), the cultivars presented the lowest values for oil content. Group IV was the second for oil content, consisting only of the cultivar M 9056RR.

The formation of these groups is of fundamental importance for the choice of parent plants, since the new hybrid combinations to be established should be based on the magnitude of their dissimilarities and the potential oil content of their parents. Cruz and Regazzi (2004) suggest the non-involvement of individuals of the same standard of dissimilarity, so as not to restrict the genetic variability, and thus avoid any negative effects on gains to be obtained from the selection. Thus, in this study, the following hybridisations should be avoided: M 8766RR x BR/EMGOPA 314, M 8766RR x P98R91 and BR/EMGOPA 314 x P98R91.

The clustering established by the Tocher method allows identification of promising crosses, as well as those that may result in restricted variability in segregating generations, such as those performed between parent plants of the same group. The following hybridisations therefore are expected to be promising: M 8766RR x M 9056RR; BR/EMGOPA 314 × M 9056RR; P98R91 x M 9056RR since the cultivars were 
Table 4 - Dissimilarity among soybean cultivars in relation to the characteristic, of oil content, based on the generalised Mahalanobis distance $\left(\mathrm{D}^{2}\right.$ ii $)$

\begin{tabular}{|c|c|c|c|c|c|c|c|c|c|c|}
\hline Cultivar $^{1}$ & 2 & 3 & 4 & 5 & 6 & 7 & 8 & 9 & 10 & 11 \\
\hline 1 & 16.31 & 20.16 & 3.64 & 16.91 & 5.69 & 5.44 & 31.75 & 30.12 & 3.87 & 2.51 \\
\hline 2 & & 8.69 & 24.85 & 27.91 & 24.96 & 32.68 & 16.02 & 23.34 & 24.79 & 27.17 \\
\hline 3 & & & 36.98 & 30.92 & 21.40 & 33.66 & 4.30 & 7.16 & 38.36 & 24.55 \\
\hline 4 & & & & 14.80 & 9.19 & 4.71 & 49.30 & 46.94 & 0.59 & 7.49 \\
\hline 5 & & & & & 7.74 & 9.37 & 34.33 & 29.15 & 20.14 & 19.79 \\
\hline 6 & & & & & & 2.1 & 25.60 & 19.50 & 11.57 & 3.62 \\
\hline 7 & & & & & & & 41.40 & 34.30 & 6.96 & 3.69 \\
\hline 8 & & & & & & & & 1.87 & 50.74 & 33.34 \\
\hline 9 & & & & & & & & & 49.32 & 28.16 \\
\hline 10 & & & & & & & & & & 7.69 \\
\hline
\end{tabular}

Cultivars': 1 (P98Y51), 2 (P98Y70), 3 (P99R01), 4 (P98R91), 5 (M 9056RR), 6 (M 9144RR), 7 (M 8766RR), 8 (M 8867RR), 9 (M 8527RR), 10 (M-SOY 9350), 11 (BR/EMGOPA 314)

Table 5 - Grouping by the Tocher method, based on the generalised Mahalanobis distance, of 11 soybean cultivars for oil content, in four environments in trials of the 2009/2010 crop

\begin{tabular}{cc}
\hline Group & Cultivar \\
\hline I & P98R91; M-SOY 9350; P98Y51; M 8766RR; BR/EMGOPA 314 e M 9144RR \\
II & M 8867RR; M 8527RR e P99R01 \\
III & P98Y70 \\
IV & M 9056RR \\
\hline
\end{tabular}

dissimilar in oil content (Tables 2 and 4) and presented a high average for this characteristic (Table 2).

\section{CONCLUSIONS}

1. The cultivars M-SOY 9350, M 8766RR and BR/ EMGOPA 314 showed a higher oil content and more efficient use of available phosphorus in the soil, being the most suitable for the production of biodiesel;

2. The hybridisations, M 8766RR x M $9056 \mathrm{RR}, \mathrm{BR} /$ EMGOPA 314 x M 9056RR, P98R91 x M 9056RR are promising for obtaining segregating populations for oil content.

\section{REFERENCES}

ALBRECHT, L. P. et al. Teores de óleo, proteína e produtividade de soja em função da antecipação da semeadura na região oeste do Paraná, Bragantina, v. 67, n. 4, p. 865-873, 2008.
BARBOSA, V. S. et al. Comportamento de cultivares de soja, em diferentes épocas de semeaduras, visando a produção de bicombustível. Revista Ciência Agronômica, v. 42, n. 3, p. 742-749, 2011.

CEOLIN, A. C. G. et al. Genetic divergence of the common bean (Phaseolus vulgaris L.) group carioca using morpho-agronomic traits by multivariate analyses. Hereditas, v. 144, n. 1, p. 1-9, 2007.

CLEMENTE, T. E.; CAHOON, E. B. Soybean oil: genetic approaches for modification of functionality and total content. Plant physiology, v. 151, n. 3, p. 1030-1040, 2009.

CRUZ, C. D.; REGAZZI, A. J.; CARNEIRO, P. C. S. Modelos biométricos aplicados ao melhoramento genético. 3. ed. Viçosa: UFV, 2004. 279 p.

CRUZ C. D. Programa Genes: Aplicativo computacional em genética e estatística. Versão Windows. Viçosa: UFV, 2007.

EMPRESA BRASILEIRA DE PESQUISA AGROPECUÁRIA. Tecnologias de Produção de Soja - Região Central do Brasil 2009-2010. Londrina, 2010. 262 p. (Sistemas de Produção, 13).

FEHR, W. R. et al. Stage of development descriptions for soybeans, Glycine max L. Merrill. Crop Scienc, v. 11, n. 6, p. 929-931, 1971. 
FERRÃO, M. A. G. et al. Genetic divergence on common bean under tropical winter conditions. Pesquisa Agropecuária Brasileira, v. 37, n. 8, p. 1089-1098, 2002.

FISCHER, K. S.; JOHNSON, E. C.; EDMEADS, G. O. Breeding and selection for drought in tropical maize. Mexico: CIMMYT, 1983.

GOLDEMBERG, J. NigRO, F. E. B. COELhO, S. T. Bioenergia no Estado de São Paulo: situação atual, perspectivas, barreiras e propostas. São Paulo: Imprensa Oficial do Estado de São Paulo, 2008. 152 p.

INSTITUTO ADOLFO LUTZ. Normas analíticas do instituto Adolfo Lutz. Métodos químicos e físicos para analise de alimentos. São Paulo: IAL, 2005. 317 p. v. 1.

LIAO, H. et al. Phosphorus and Aluminum Interactions in Soybean in Relation to Aluminum Tolerance. Exudation of Specific Organic Acids from Different Regions of the Intact Root System. Plant Physiology, v. 141, n. 2, p. 674-684, 2006.

MACHADO, C. D. et al. Genetic divergence among genotypes of common bean through of multivariates techniques. Ciência Rural, v. 32, n. 2, p. 251-258, 2002.

MAEHLER, A. R. et al. Qualidade de grãos de duas cultivares de soja em função da disponibilidade de água no solo e arranjo das plantas. Ciência Rural, v. 33, n. 2, p. 213-218. 2003.

MINUZZI, A. et al. Rendimento teores de óleo e proteínas de quatro cultivares de soja, produzidas em dois locais no estado do Mato Grosso do Sul. Ciência Agrotecnica, v. 33, n. 4 , p. $80-93,2009$.

PELUZIO, J. M. et al. Desempenho de cultivares de soja, em duas épocas de semeadura, no sul do Estado de Tocantins. Bioscience Journal, v. 22, n. 2, p. 69-74, 2006.

PIAIA, F. L. et al. Eficiência da adubação fosfatada com diferentes fontes e saturação por bases na cultura da soja [Glycine max (L) merrill]. Ciencia e Agrotecnologia, v. 26, n. 3, p. 488-499, 2002.

RAO, C. R. Advanced statistical methodos in biometric research. New York: John Willey, 1952. 390 p.

RODRIGUES, L. S. et al. Divergência genética entre cultivares locais e cultivares melhoradas de feijão. Pesquisa Agropecuária Brasileira, v. 37, n. 2, p. 1285-1294, 2002.

SCAPIM, C. A.; CARVALHO, C. G. P; CRUZ, C. D. Uma proposta de classificação dos coeficientes de variação para cultura do milho. Pesquisa Agropecuária Brasileira, v. 30, n. 5, p. 683-686, 1995.

SBARDELOTTO, A. I. G.; LEANDRO G. V. Escolha de cultivares de soja com base na composição química dos grãos como perspectiva para maximização dos lucros nas indústrias processadoras. Ciência Rural, v. 38, n. 3, p. 614-619, 2008.

VALADÃO JUNIOR, D. et al. Adubação fosfatada na cultura da soja em Rondônia. Scientia Agraria, v. 9, n. 3, p. 369375,2008 . 